social services colleagues, his potential for influence is open-ended.

Besides the more formal aspects of the work of a district community physician there is a whole host of informal ways in which he or she can participate in the health care of the community. Agreed this is largely in an advisory capacity, but in our modern democracy this really has to be the way rather than the dictatorial approach of bygone years. As a former colonial "director" of health services, this concept is as difficult for me as it will be for many previous medical officers of health. In spite of this I firmly believe that reorganisation allows the district community physician more rather than less opportunity to play an important role in health care. This is so even allowing for the difficulties created by hospital consultants being employed by the regional health authority, general practitioners having independent contractor status with the family practitioner committee, and others being employed by the area health authority.

Is this all too idealistic? Maybe, but perhaps this would be a welcome change from the unhealthy contemporary influence of ideology. If we are to restore the credibility of community physicians and of the profession as a whole then there is a case for a bit of idealism and positive thinking. In spite of economic depression and the shadow of central government intervention there is indeed much that we can do at a local level.

At long last community physicians have a marvellous opportunity to break away from the old Dr Snoddie image. We have even a chance now to become completely committed, along with our general practitioner colleagues, to the total health care of the community.

J G AVERY

Warwickshire Area Health Authority,

South District Leamington Spa

SIR,-Dr J S Horner (31 July, p 338) urges community physicians to return to their "common core of knowledge and practice" and to cease fragmenting their emerging specialty. Unhappily this approach, which has predictably followed early decisions taken by the newly created Faculty of Community Medicine, is not likely to change for some time to come.

When first seeking founder members the faculty laid down basic and firm criteria for admission; these were not universally applied and the membership became much larger than some who had been properly qualified had anticipated. Furthermore, the acceptance by faculty representatives at specialist appointment committees of a number of appointments of candidates who were not even members of the faculty as constituted and who had little training, experience, and responsibility in the specialty has not enhanced the opinion of the specialist grade held by other senior members of the profession. At the time of the reorganisation of the Health Service it was known that there would be a shortage of suitable candidates for specialist posts-as Dr Horner reminds us (31 July, p 322 ) nearly $20 \%$ of established posts still remain unfilled. However, to subordinate the control of quality and standards to an assumed need to complete an untried management structure is to repeat the error committed by the General Medical Council in uncritically registering certain overseas doctors. The Merrison Report ${ }^{1}$ (para 187) criticised this attitude as "a willingness . . . to allow its duty as the protector of medical standards to be compromised by the manpower requirements of the NHS." Repeated refusal to appoint appropriate candidates to the subspecialist grade, which had been expressly created in community medicine for those who did not merit specialist status, has not improved an already difficult situation. The true test of Dr Horner's plea is to consider the extent to which specialists could, and would, readily exchange duties for prolonged periods and whether (now that appointments as deputy are no longer made) all specialists could immediately act in place of a regional or area medical officer.

Thus there are now a number of subspecialties in community medicine and it will be some years before any real progress can be made to eliminate this reality. It would have been far better if fewer specialist posts had been created; if standards for appointment had been firmly applied (how many specialists so far appointed really possessed the wide background of experience and training implied by $\mathrm{Dr}$ Horner?); and if more emphasis had been placed on medical and administrative support for those fewer specialists so that they could function as consultants and advisers. Absence of such support is not properly and lastingly solved by the creation of further specialist posts. Is it really surprising that those who are lost in the wilderness without the necessary preparation and experience for such a venture abandon the promise of better things and return to older and more comfortable ways? Many will welcome $\mathrm{Dr}$ Horner's sensible proposal that the Central Committee for Community Medicine should redefine the specialty (and specialist work ?) and its role.

Hursley, Southampton

R B RoBINSON Report of the Committee of Inquiry into the Regulation
of the Medical Profession. London, HMSO, 1975

SIR,-As a registrar in community medicine I am frequently asked to explain to clinical colleagues how I see the future of community medicine. Environmental health and the control of pollution will certainly remain an interest of the community physician, but the importance of this aspect has already been well described in your columns and I feel needs no further comment. However, I believe that activity in this area is only part of the community physician's commitment and that there are other aspects of community medicine that ought to be brought to the attention of the profession. I believe that the basis of future discussion and comment on the role and functions of the community physician ought to be based on the following personal views.

I believe that medical practice is more than the business of selling cures whether such cures are paid for privately or by the State. I believe that the emphasis that has been placed on science, technology, and exact measurement in medicine over the past few decades has had an almost fatal effect on the attitudes and enthusiasm of countless of my contemporaries in medicine.

I believe that as doctors our minds must be welded to our emotions so that we can help our patients with sympathy (Greek sym= with, pathy $=$ feeling) and understanding. I believe that the medical art should be centred on the identification of the emotional, physiological, and spiritual needs of those who come to us who are diseased in any area of their experience of life. Having identified the needs of an individual we must apply our art-engaging our emotions, our minds and our spirits-sometimes using the resources available at the technologist's door but more often restoring ease by our ability to listen and understand.

I believe that community medicine is the natural extrapolation of this concept to human groups. I believe that just as individuals can be identified with particular needs so too can groups of people be found who share a common need. For example, there are those with cancer of the stomach, those with haemophilia, those who despair and think of suicide, etc. The list is endless. I believe that the community physician's art is to employ enthusiastically all his personal resources of intellect, emotion, and vision to establish services that assist the clinician in his task to meet the identified needs of his patients. Sometimes this will mean organising the purchase of expensive technological equipment like impedance audiometers or endoscopes, and at other times he will encourage spending on the improvement of the support services available to people in their own homes, but always a full range of services will be the aim, and this will naturally depend on the identified needs of groups within his district.

I believe that this concept implies the complete interdependence of clinicians and community physicians if needs are to be identified and met and society is to be rehumanised.

No doubt there will be many who have read this far who are feeling that all this is idealistic nonsense, yet I believe that without such a vision our profession and the people will perish.

Forthampton, Glos

Malcolm RigleR

\section{Thyrotoxic vomiting}

SIR,-In their excellent paper Dr F D Rosenthal and his colleagues (24 July, p 209) draw attention to thyrotoxic vomiting. Our recent experience prompts us to present the following illustrative case.

A 46-year-old woman developed flu-like pain in the neck and extremities. The pain disappeared after a few days but she became anorectic and started to vomit after most meals. One month later she had lost $9 \mathrm{~kg}$ and was admitted to hospital. On admission her blood pressure was $130 / 80 \mathrm{~mm} \mathrm{Hg}$ and pulse rate $110 / \mathrm{min}$. The thyroid was of normal size but there was a questionable nodule in the right lobe. There was no exophthalmos, tremor, or sweating and the patient looked calm. The abnormal initial laboratory findings were raised aspartate and alanine transferase levels (75 IU/l and $315 \mathrm{IU} / 1$ respectively, normal $<20 \mathrm{IU} / \mathrm{l})$. The serum cholesterol concentration was $3.3 \mathrm{mmol} / 1(127 \mathrm{mg} / 100 \mathrm{ml})$ and the serum protein-bound iodine concentration $1800 \mathrm{nmol} / \mathrm{l} \quad(23 \mu \mathrm{g} / 100 \mathrm{ml})$. The latter was attributed to contamination. Thyroid autoantibodies were not present. Despite treatment with antiemetic agents her vomiting persisted and she had to be treated with intravenous fluids. When after 10 days other thyroid studies (T3, T4) were reported there was no doubt of the diagnosis. She was started on $40 \mathrm{mg}$ of carbimazole daily. In five days the vomiting stopped completely and the patient made a rapid recovery.

The present case further stresses the diagnostic difficulties associated with monosymptomatic thyrotoxic vomiting. Although hyperthyroidism was initially taken into ac- 
count, the clinical picture and the markedly increased liver enzyme values were misleading and the protein-bound iodine result was thought to be erroneous. Thus the patient was on parenteral nutrition for almost two weeks before a firm diagnosis was made. The treatment resulted in dramatic improvement within a few days.

\section{Matti SAarni}

ELLI KoIvUneN

Hatanpää Hospital,

Tampere, Finland

SIR,-The paper by Dr F D Rosenthal and others (24 July, p 209) prompts us to record a recent patient with thyrotoxicosis who, while not vomiting, was decidedly liverish.

A 63-year-old farmer presented with three months' history of loss of weight ( $25 \mathrm{~kg}$ ), shivering, sweating, and high backache. Mild scleral icterus and a pulse rate of $90 / \mathrm{min}$ were present together with a palpable liver edge and a palpable spleen. Initially the patient was investigated for neoplasm with a negative result. A serum thyroxine concentration of $412 \mathrm{mmol} / 1(32 \mathrm{mg} / 100 \mathrm{ml})$ reverted to within normal limits (46-148 mmol/1 (5-11.5 mg/ $100 \mathrm{ml})$ ) after treatment with radioactive iodine, as did abnormal liver function tests, the serum bilirubin level falling from $44.5 \mu \mathrm{mol} / 1(2.6 \mathrm{mg} /$ $100 \mathrm{ml})$ to $13.7 \mu \mathrm{mol} / 1(0.8 \mathrm{mg} / 100 \mathrm{ml})$, serum albumin rising from 28 to $37.5 \mathrm{~g} 1$ and total protein from 55 to $70 \mathrm{~g} / \mathrm{l}$, and the Thrombotest result rising from $45 \%$ to $100 \%$

Dr Rosenthal and his colleagues mention "slightly raised" liver enzyme levels in four cases out of seven and in their first case the serum bilirubin level "was raised" at $25: \mu \mathrm{mol} / 1$ $(1.5 \mathrm{mg} / 100 \mathrm{ml})$. It is worth remarking that our patient never suffered from anorexia of any kind during the course of his illness and all abnormalities disappeared after treatment with ${ }^{131} \mathrm{I}$. A subsequent liver scan was normal.

Liver abnormalities have, of course, been described in thyrotoxicosis but rarely of sufficient note to orientate the diagnostician clinically towards a gastrointestinal investigation.

ThOMAS KieRnAN M McElligotT

Portiuncula Hospital,

Ballinasloe,

\section{Management of diabetic pregnancy}

SIR,-Your leading article (31 July, p 267) on the management of diabetic pregnancy is rather out of date. Firstly, you observe that the perinatal mortality is now "close to $10 \%$ " when in fact it is now much less than this. At this hospital it has decreased from $9^{\circ}{ }_{0}$ of 176 deliveries in the five years $1966-70^{1}$ to $4^{\circ}{ }^{\circ}$ of 144 deliveries in the period 1971-4, ${ }^{2}$ which is maintained at $3.5^{\circ}{ }_{0}$ when 1975 is included (total of 173 deliveries). This improvement is at least partially due to close collaboration between physician, obstetrician, and paediatrician, which is crucial in the management of diabetic pregnancy in order to achieve the careful antenatal and intrapartum monitoring which is needed. ${ }^{3}$ Furthermore, quoting a publication now nine years old, you observe that respiratory distress is the most common cause of death, whereas it is now exceptionally rare and we have had no such deaths for several years. ${ }^{2}$ You make no mention of the increasing fetal loss from congenital malformations, which are now the commonest single cause of perinatal death. ${ }^{24}$ Finally, you say that the insulin requirement falls "soon after delivery." In fact the fall is immediate and there is a great danger of very severe hypoglycaemia if the insulin dose, which may have increased two- or three-fold during pregnancy, is not reduced to prepregnancy levels on the day of delivery.

\section{A PYKe}

J M BRUDENEL P J WATKINS H R GAMSU N L ESSEX

Kings College Hospital, London SE5

'Essex, N, et al, British Medical fournal, 1973, 4, 89. - Essex, N, British fournal of Hospital Medicine, 1976, 15,333 . Brudenell, $M$, in Carbohydrate Metabolism in Pregnancy and the Newborn, $\mathrm{H} \mathrm{W}$ Sutherland and
$\mathrm{J} M$ Stowers. Edinburgh, Churchill Livingstone, 4 Soler, N G, et al, Quarterly fournal of Medicine, 1976,
45, 303.

***The recent figures for perinatal mortality obtained at King's College Hospital are unusually good, but the figure of "nearly or slightly below $10^{\circ}$ " may be regarded as more typical in the country generally. The leading article did not say that hyaline membrane disease or "respiratory distress" is the commonest cause of death but rather that it has been found to be the commonest cause of death of babies born prematurely to diabetic mothers, the "has" being used because a relatively old source of information was quoted. The decreased incidence of this cause of death is doubtless due to several factors, of which a significant one is the study of amniotic fluid mentioned in the previous sentence. Considerations of space prevented direct reference to the importance of congenital malformations, but this is one of the main factors which make it, as we said, "increasingly difficult to reduce the perinatal mortality in diabetics any further." The final point, whether the insulin requirement falls "soon after delivery" or "immediately," is hard to judge as the mother usually has an intravenous drip of glucose running at this time, but certainly the insulin dose should be decreased from the time of delivery.-ED, $B M \mathcal{H}$.

\section{Urinary retention in women}

SIR,-I am glad that the letters from Mr S L R Stanton and $\mathrm{Mr} \mathrm{T}$ Moore were published together (14 August, p 420). I see about one woman each year who has "female prostatic obstruction" exactly as described by $\mathrm{Mr}$ Moore; as he says, they respond well to the removal of the obstruction by endoscopic resection. So I am surprised that $\mathrm{Mr}$ Stanton found no such case in his series of 27 women with retention or a slow stream.

But why does Mr Stanton consider pressureflow studies with sphincter electromyography so important? It is safe to assume that his 27 patients were thought to have "acute retention," "chronic retention," or "a noticeably slow stream" as the result of a good history and a simple examination. To determine a drug-induced aetiology requires only careful inquiry and the trial substitution of the drug thought responsible. Similarly, a neurological aetiology is surely determined by the history and the relevant clinical examination. Maybe there is now a urodynamic finding that is actually diagnostic of hysteria, but I doubt it.
I have seen two women with retention which had been elsewhere considered to be due to hysteria. One, with repeated painful episodes of acute retention, had a cyst of the urethra and trigone; the other, with chronic retention, had a "female prostate"-both responded well to endoscopic resection.

In 1976, when impecunious area health authorities like mine cannot provide a consultant with a desk, let alone an office, it behoves the teaching hospitals to consider carefully, when advocating such very expensive gadgetry, whether equally good results could not be obtained with a pin and a bit of cottonwool.

North Ormesby Hospital,

ROGER HOLE Middlesbrough, Cleveland

SIR,-While I am in agreement with Mr S L R Stanton (14 August, p 420) that hysteria may be an important aetiological factor in many cases of acute retention of urine in women, I must disagre $\epsilon$ that chronic retention "may be considered to be the result of a single or repeated episode of acute urinary retention."

Once obvious obstructive urological (for example, stone, tumour), neurological, and gynaecological Jesions and a history of drug ingestion have been excluded $w^{1}$ believe that chronic urinary retention is not a single entity but consists of at least two different aetiological groups. The first is characterised by a residual urine volume of less than $500 \mathrm{ml}$ and displays the self-perpetuating spiral of chronic inflammatory changes at the bladder neck, ${ }^{1}{ }^{2}$ residual urine, and infection; the second is characterised by the "modesty type" of bladder with a residual urine volume in the region of 11 or more. While a hysterical personality trait may be found in some of the women in this second group there is, I would propose, no evidence that the first group may progress to the second and no evidence that, except perhaps in an immediate postoperative period, episodes of acute retention of urine in women may pass unnoticed and progress to chronic retention.

GERALD J JARVIS

St Mary's Hospital,
Leeds

${ }^{1}$ Fox, M, Jarvis, G J, and Henry, L, British fournal of ' Evans, A T, fournal of Urology, 1971, 105, 245.

\section{Abortion and maternal deaths}

SIR,-Dr Ann Cartwright in her letter (24 July, p 232) is quite right. There exists much evidence of undue delay in reaching decisions to abort. Certainly, there is enough to justify reforming action now rather than at some unspecified time in the future.

For example, a recent survey ${ }^{1}$ in the Cardiff area shows that a significant proportion of family practitioners consider the service at the main hospital (University Hospital of Wales) to be unsympathetic or unsatisfactory or inadequate in substantial part because of delays by consultants in making appointments. Incidentally, the survey shows that about half the women in Cardiff seeking help with termination have to be referred outside the area because of prevailing attitudes at the University Hospital. Only 10 of the 197 family practitioners in the South Glamorgan Area (15\% of respondents) were prepared to 